\title{
The International Financial Reporting Standards and Firm Performance: A Systematic Review
}

\author{
Wafaa Salah ${ }^{1}$ \\ ${ }^{1}$ Department of Accounting, The British University in Egypt, Cairo, Egypt \\ Correspondence: Wafaa Salah, Department of Accounting, The British University in Egypt, Cairo, Egypt.
}

Received: May 12, 2020

Accepted: May 28, 2020

Available online: June 11, 2020

doi:10.11114/afa.v6i2.4851

URL: https://doi.org/10.11114/afa.v6i2.4851

\begin{abstract}
This study reviews the accounting literature which investigates the effects of International Financial Reporting Standards (IFRS) on firms' financial performance to answer a debating question of how effective are the accounting standards in affecting financial performance and to provide guidance for future studies. The focus of the review is three primary streams, first, reasons and evidence of differences between countries in accounting practices; second, theories justifying the transition from local Generally Accepted Accounting Principles (GAAP) to IFRS; Third, the effect of accounting standards on firms' financial performance regarding three broad groups: (1) Common law countries (2) Civil law countries, and (3) Middle East and North Africa (MENA) region countries affected by both sharia law and civil law. The review demonstrates that the transition from local GAAP to IFRS has been successful in affecting firms' financial performance measures in less shareholder-oriented civil law and MENA region countries. This was attributed to the IFRS fair value orientation, which causes volatility in the statement of financial position and financial performance figures. These impacts, however, usually vary between countries, depending on the pre-transition differences between local GAAP and IFRS. The more the difference, the more volatile the financial performance measures, particularly the profitability ratios. This review's findings have implications for other jurisdictions, particularly developing countries, where IFRS adoption is already underway. In addition, managers, investors, practitioners, and standard setters can use this review to identify the factors that have been found to influence firm performance, especially in a globalized economy that is increasingly cross-listed.
\end{abstract}

Keywords: civil law, IFRS, common law, GAAP, financial ratios, general review

\section{Introduction}

The widespread movement toward globalization has been the concern of many countries, especially developing countries in the last few decades due to its significant economic consequences. Hence, the adoption of a worldwide and uniform Financial Reporting Standards is gaining ground due to emerged challenges as comparability, reliability, and understandability among others (Adeuja, 2015). According to Uzoma et al. (2016), comprehensive disclosure and fair presentation required by financial statements comply with IFRS are anticipated to eliminate or decrease discrepancies resulting from cross-border comparisons of financial statements, encourage clarity and improve the financial reporting quality of a firm engaged in both local and international operations which may impact firms' profit positively. Approximately 140 countries around the globe allow or require the adoption of IFRS for publicly listed firms, including 50 developing countries. This was considered one of the most significant innovations in accounting history since 2005(Houqe, 2018).

IFRS was developed by the International Accounting Standard Board, which is a private entity in London whose primary goal is to create a high-quality accounting standard for international use in preparing financial reports(Parrott, 2017). The number of donors to IASB reached approximately 400 donors by 2008 originating from multinational firms around the world(Larson \& Kenny, 2011). The European Union (EU) issued a regulation in 2002 requiring all firms listed on their regulated markets to comply with the IFRS from 2005 onwards. In 2007, the US Securities and Exchange Commission eliminated the demand in Form 20-F for listed foreign firms adopting IFRS to reconcile IFRS with US GAAP(Bao, Lee, Romeo, \& Accounting, 2010).

Standard setters and practitioners especially in developing countries where low financial reporting quality affects their ability to attract foreign capital are considering the adoption of IFRS (Samaha \& Khlif, 2016). For instance, there is a 
premise over the past few decades that IFRS enhances transparency and limits managers ' choices for managing financial statements which may affect the firms' financial reporting quality and hence firms' financial performance (Newman et al., 2016). However, there are several arguments in literature over the last few decades regarding the desirability and viability of having a unified worldwide set of financial reporting standards and its financial consequence (Houqe, 2018).

Those in favor of a unified reporting standards claim that a unified set of harmonized accounting standards will improve investor protection (Lantto \& Sahlström, 2009), reduce information asymmetry (Armstrong, Barth, Jagolinzer, \& Riedl, 2010), make financial statements more comparable and transparent across countries (Horton, Serafeim, \& Serafeim, 2013), remove cross border acquisitions obstacles (Abdul-Baki, Uthman, \& Sannia, 2014), reduce cost of capital(Naderian \& Mahadevappa, 2014), and raise the quality level of accounting practices (Parrott, 2017). von Alberti-Alhtaybat, Hutaibat, and Al-Htaybat (2012) provide evidence that IFRS facilitates the assessment of prospective foreign securities investments by investors which assists firms to access the capital market. Abdul-Baki et al. (2014) indicate in their study that the implementation of IFRS in any country is anticipated to increase stockholders' wealth either in the long or short term. They added that the shift from local GAAP to IFRS results in changes in the representation of the net income and net asset which may lead investors to revalue the firm's equity which is consistent with the value maximization theory that describes all the firm's operations as profit-seeking.

On the other hand, those in opposition claim that the different traditions and nationalism cause difficulties in the transition to a unified set of accounting standards and might cause standards overload. For instance, Alp and Ustundag (2009), showed that Turkey faced many difficulties in transferring from local GAAP to IFRS due to the complex nature of IFRS and knowledge gaps. Moreover,Iatridis and Rouvolis (2010) mention that the IFRS transition poses difficulties for firms, including technical differences, change, modified costs, inadequate experience and expertise, and inadequate time factor. Furthermore, IFRS fair value orientation is likely to introduce fluctuations in the statement of financial position and earnings which may distort the firm's financial profile. Weigel (2011) believes that the comparability of financial statements between countries cannot be accomplished because each country has developed a country version of IFRS to tackle domestic problems; as a result, full comparability is excluded.

Additionally, Tanko (2012) states that IFRS is a principle-based approach that provides less guidance on how transactions should be handled and provide management much flexibility to choose among a number of accounting alternatives. This may lead to higher earnings management in developing countries due to weak institutions, weak corporate governance practice, and unstable political and economic environment and hence, unsuccessful adoption of IFRS. Uzoma et al. (2016) added that constraints on trade, environmental, economic, culture and political differences between countries delay realistic harmonization with IFRS. Khamis (2016) tried to test the Egyptian accountants' and auditors' understanding of IFRS 15 which will be applied in January 2020. He found that the Egyptian accountants and auditors in general are not yet prepared to embrace and have insufficient understanding of IFRS15, Revenue from Contracts with Customers, in addition to the fear from the new requirements for revenue recognition (which enhanced freehand and professional judgment in recognition of revenue) and its possible effect on various sectors.

This dispute is concerned with the benefits the firms will have from the proposed conversion. The fundamental modifications in the financial statement accounts and the associated financial ratios have an impact on stakeholders relying on accounting numbers and may affect their investment decisions (Lueg, Punda, \& Burkert, 2014). Hence, investigating the effects of IFRS on firm financial performance may be considered an important research question that needs more investigation, especially for developing countries. Identifying whether there are significant differences between financial performance measures as profitability and liquidity before and after IFRS adoption will help managers and regulators to determine if the advantages of this transition will outweigh the expenses incurred. Hence, the review objective is to identify, summarize, and compare the collected studies to investigate how previous studies address the impact FRS have on firms' financial performance. To achieve the review objective, the following research questions were identified as follows:

RQ1: Is there any evidence for a difference in accounting practices between countries?

RQ2: What are the different theories justifying the transition from local GAAP to IFRS?

RQ3: Do reviewed studies suggest that the financial performance measures prepared under IFRS financial statements and local GAAP of economic entities are significantly different?

RQ4: Do financial performance measures prepared under IFRS financial statements indicate higher performance than those under local GAAP?

Answering the above research questions may assist standards setters, practitioners and managers in understanding how FRS affects firms' performance and in adding to the comprehension of the studies' theoretical backgrounds and historical foundations, both of which continue to serve as justification for this research. This also helps to put the 
reviewed research in the right view. As Figure 1 shows the growing literature investigating the impact of IFRS on financial performance, this means that IFRS is being increasingly adopted in several jurisdictions which highlights the significance of this research area. This study discusses the opportunities for future research.

The findings of this study show that significant changes in the financial performance ratios, particularly the profitability and liquidity ratios after the transition to IFRS in less shareholder-oriented civil law countries like Finland and MENA region countries. The main difference was due to the reality that IFRS values assets and liabilities at fair value which causes volatility in the balance sheet figures. In addition to the allocation of some unrealized gains and losses to both statements of financial performance and other comprehensive income which may affect financial performance ratios. On the other hand, the majority of the surveyed studies show an insignificant change in financial ratios in more shareholder-oriented common law countries as Australia. This was because IFRS resembles local GAAP originated from common law countries. Moreover, no significant differences for countries whose local GAAP was a translation to IAS as Nigeria.

This study contributes to the literature by incorporating and analyzing studies from a wide range of research topics covering various elements of the effect of the transition to IFRS on financial performance. Understanding the effects of different accounting standards on firm financial performance is important in assessing the costs and benefits of the transition to IFRS and informing the discussion on the role of various accounting standards in financial reporting. This paper is organized as follows: Section 2 presents the scope and method used to conduct the review processes. Section 3 presents the literature review and summarizes the research questions' results and finally the conclusion and opportunities for future research.

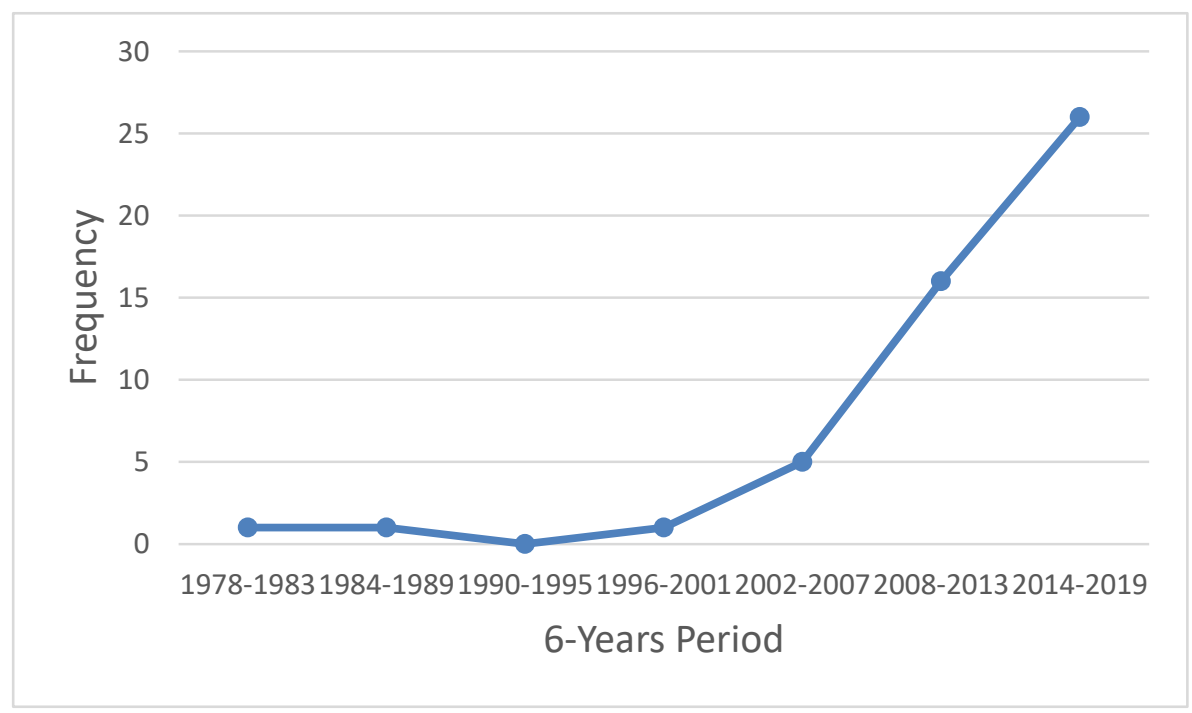

Figure 1. Distribution of reviewed articles (1978-2019)

\section{Literature Review Method and Scope}

This review study was performed following the Kitchenham (2004) guidelines. A formal search approach was used to identify suitable research papers that might provide answers to the study's research questions. This research used several online databases to identify targeted research papers, namely: Google Scholar, Dar Al Mandumah, Egyptian Knowledge Bank, SCOPUS, Science Direct, and PubMed. Rankings and indexes for academic journals as Science Direct and Scopus provide a useful means of signaling quality (Ott \& Michailova, 2018). Besides, Cairo University Library was used in this search strategy. The search terms used in the search inquiry forms are financial performance, IFRS, FRS, profitability, accounting standards. A list of primary studies was obtained from the searches in this search space. This study covers published articles in peer-reviewed journals, conference papers and thesis. In addition, it covers unpublished thesis.

This review used the exclusion and inclusion criteria that identify whether each research retrieved should be included in the literature review. The following inclusion criteria had to be met for an article to be included in this review: (1) the paper should be written in English or Arabic; (2) papers should be in the area of accounting standards whether international or local because of the origin of this stream of studies; (3) the studies that has been done up to August 2019; and (4) Available in full text; The exclusion criteria applied in this review are: (1) all papers published as 
abstract only or in the form of talks or tutorials; (2) papers in the area of accounting standards adopted but did not mention financial performance; (3) research papers not match the search keywords; (4) papers with poor statistical techniques or poor arguments; and (5) Manuscript are not written in English or Arabic. There is no agreed quality definition to evaluate the quality of the research papers selected. However, this review employs the Critical Appraisal Skills Programme (CASP) to evaluate the quality of the retrieved research papers and select the studies that enhance the relevance of the outcomes obtained in the review (Programme, 2013). The assessment criteria used from the CASP are listed in Table 1.

Table 1. Quality assessment criteria:

Evaluating the validity of the research

The objective of the study was stated clearly

The methodology employed was appropriate

The data collected was adequate to address the research problem

Evaluating the results of the research

$\begin{array}{ll}\text { The data analysis used was accurate enough } & \text { Agree/Neutral/Disagree }\end{array}$

There was a clear statement of findings

Agree/Neutral/Disagree

Agree/Neutral/Disagree

Agree/Neutral/Disagree

Agree/Neutral/Disagree

Eighty-two studies were retrieved from the search criteria. After adopting the inclusion and exclusion criteria, fifty-nine were selected and finally, fifty studies with dates ranging from 1978 to 2019 were used in this review after applying the CASP as shown in Figure 1. The researcher extracted from each paper the research objectives, findings, methodology, and conclusion. These key points were organized to be able to compare studies and reach to Interpretations of a higher order.

\section{Literature Review}

\subsection{Theoretical Framework}

Several researchers tried to investigate the causes of differences in accounting standards between countries. Doupnik and Perera (2019) mention five factors that may cause accounting standards diversity to a large degree which are taxation, the legal system, inflation, political and economic ties and finally providers of financing. For instance, in civil law countries such as Finland, Sweden, Japan, Germany and Belgium, firms have traditionally depended as a major source of funding on family members, banks, and the government. They obtain financial data directly from management, or may even be involved in firms' decision making which causes less demand for public accountability and information disclosure and therefore published reports tend to be less transparent. On the other side, common law countries as the US and Canada, shareholders are a major provider of financing which requires more transparency and disclosure to investors (Ding, Hope, Jeanjean, \& Stolowy, 2007). Further, Lantto and Sahlström (2009) point out that the differences between country-level financial systems and the differences between ways to resolve information asymmetry illustrate the differences between accounting practices across countries.

Moreover, Lueg et al. (2014) point out that the variations in legal systems cause differences between IFRS and local GAAP. For instance, in civil law countries, accounting rules tend to be legislated, very detailed, and accounting practice tends to be more conservative so as to reduce the amount of income subject to taxation. On the other hand, the accounting standards developed by non-legislative organizations in common law countries such as the United Kingdom are less governed by the statute which allows judgment to be exercised. IFRS resembles local GAAP originated from common law countries and hence, firms in these countries should experience fewer differences in financial statements after an IFRS transition (Byard, Li, \& Yu, 2011). For instance, d'Arcy (2001) investigated the financial statements of 15 firms adopting local GAAP. He found that North America which follows the common law regime has an accounting system that is concerned more about investors and creditors. It is more market-oriented and requires detailed disclosure to help investors in making rational decisions. On the other hand, he found that Continental European which follows the civil law regime has an accounting system that is designed to provide information for banks, tax authority and government and hence few disclosures to investors. As a result, the level of differences between local GAAP in continental European countries and IFRS is high as IFRS is capital oriented. Doupnik and Perera (2019) noted a clear connection between the legal system, tax compliance, funding source, and resemblance to IFRS.

Additionally, Atu, Atu, and Atu (2014) tried to compare the accounting standards in Nigeria, the United States of America and the United Kingdom. They found differences in the measurement of intangible assets, research and development, inventory and other accounts. They mention that accounting standards are influenced by different actors as government, financial analysts, investors, employees, and the socioeconomic environment. The accounting standards of different countries should harmonize not only with IFRS but with corporate and tax rules in each country. Similarly, Espinosa, Maquieira, Diaz, and Abarca (2015) mention that adopting a new accounting standard is influenced by 
countries' legal and institutional environment. In the same vein, Boolaky, Omoteso, Ibrahim, and Adelopo (2018) investigate the impact of socioeconomic and political factors on the willingness of Egypt, Libya, Jordan, and the United Arab Emirates to use IFRS. The study showed how institutional development led to the present accounting practices in the four countries and showed a good comparison between these countries and other developed countries where IFRS is already in use. Besides, it revealed that Egyptian accounting standards converged strongly with IFRS while UAE and Jordan chose to adopt IFRS completely.

Conclusively, the above literature shows that the variation in the legal system, source of finance, and socioeconomic factors cause variation in accounting standards developed by each country. The literature shows differences in the recognition and measurement criteria that affect accounting figures in the financial reports. This answers the first research question of whether reviewed studies suggest that there is any evidence for a difference in accounting practices between countries.

Another stream of research tried to identify theories that motivate IFRS adoption. Several theories tried to explain why firms transfer from local GAAP to IFRS. Some of these are the economic theory of networks, signaling theory, capital needs theory and the value maximization theory. For instance, Samaha and Khlif (2016) point out that the economic theory of networks can justify the choice to adopt IFRS. Its perspective is that countries are likely to implement IFRS if geographical region's trade partners or nations are IFRS adopters as European Union (Katz \& Shapiro, 1985) which may encourage multinational operations. Furthermore, signaling theory which was developed by Spence (1978) may explain compliance with IFRS. It demonstrates how firms can reduce information asymmetry with more information disclosed in the financial reports which signal managers' intentions and expectations. Adopting IFRS may send signals to investors about the readiness of the firms to disclose more information which enhances transparency and reduce asymmetry. Vvon Alberti-Alhtaybat et al. (2012) mention that capital need theory assumes that firms issue shares and bonds to have opportunities for growth. Firms are competing for resources and this will motivate firms to comply with IFRS to acquire a cost-effective corporate capital. Additionally, Uzoma et al. (2016) point out that the value maximization theory may explain IFRS compliant financial reports. The objective of the theory is to maximize the wealth of shareholders, debtors and warrant holders in both the short and long run. Hence, it can be claimed that the transition to IFRS may lead to the maximization of the value of the firm and increase profitability ratio which may answer the second research question.

\subsection{Effect of Accounting Standards on Financial Performance}

The financial performance of a firm is a measure of success that reflects the aptitude of a firm to produce returns. The more profitable a firm, the more the financial relaxation. Lotfy (2007) has identified several financial ratios to be used in a firm's performance measurement as working capital turnover ratio, fixed asset turnover ratio, debt turnover ratio, interest rate coverage ratio, and debt service coverage ratio. Additionally, Zeller (2019) identified nine IFRS-based ratios that are consistent and comparable despite differences among countries namely: asset relationship, asset turnover, capital structure, expense insight, fixed asset usage, inventory turnover, liquidity, profitability margin, and performance return. According to Parrott (2017), the most widely used financial measures by financial experts to assess firms' financial performance are profitability, liquidity, capital structure and, market value.

Several developing countries adopted IFRS or in the process of its adoption in the last few years to enhance their firms' financial performance such as United Arab Emirates, Saudi Arabian, Egypt, and India. The adoption process is expensive and complicated (Jermakowicz \& Gornik-Tomaszewski, 2006). As a result, several studies try to examine whether IFRS adoption had an effect on the key financial ratios and the market reaction to this type of initiative. They used various financial ratios in measuring financial performance (Abdul-Baki et al., 2014, Adeuja, 2015, Atu et al., 2014, Parrott, 2017). According to Wang and Welker (2011), the transition from local GAAP to IFRS results in a shift in the firm's financial position, which may lead investors to revalue the firm's equity. This shift may be due to the variations in the balance sheet which may affect liquidity and leverage ratios or in the income statement and recognition of unrealized gains /losses which may affect profitability and coverage ratios (Blanchette et al., 2011).

Studies conducted regarding countries under the common law system reveals that countries' local GAAP is market-oriented, however, there is scarce evidence showing a limited distinction between accounting standards under common law regime and IFRS. For instance, in Canada, Blanchette, Racicot, and Girard (2011) compared 16 financial ratios for nine firms computed under both IFRS and Canadian GAAP for the same period. The ratios examined are classified into four groups namely: liquidity, profitability, coverage, and leverage. The main difference between both standards is due to the heavy reliance of IFRS on fair value accounting and comprehensive income. However, the results show no significant differences in financial performance ratios after the change from local GAAP to IFRS. This result could be due to the reality that Canada is a common law country that requires detailed disclosure to investors and has high transparency. This implies that countries with high-quality accounting standards may not have significant changes after transformation in financial performance measures. Similarly vein, Jermakowicz, Chen, and Donker (2018) 
used panel data analysis to examine the effect of IFRS on the financial statement. Although they find that the prepared financial statements are more value relevant than those under Canadian GAAP, the profitability ratios as such ROA were not significantly affected.

Abdul-Baki et al. (2014) conducted a case study to compare 24 financial ratios that were calculated under both IFRS and Nigerian GAAP over seven years. The objective is to investigate whether there exists a significant difference and such difference enhances the evaluation of the firm's financial performance by stakeholders which increases its value. The results imply that there are no statistically significant differences between the Nigerian GAAP and IFRS financial ratios. In the same vein, Adeuja (2015) examines the effect of pre(2010-2011) and post(2012-2013) IFRS adoption on the financial performance of ten Nigerian banks. The mandatory adoption of IFRS begins since 2012 and the results show that there are no statistically significant differences between pre and post IFRS adoption in performance. The same results found by Erin and Oduwole (2018). This could be due to the reality that Nigeria suffers from fragile institutions, unstable economic and political conditions that could weaken the effective application of IFRS. However, IFRS reduces information asymmetry by enhancing the comparability of the financial statements and providing more disclosure. In addition to the fact that IFRS resembles local GAAP originated from common law countries especially that Nigerian GAAP was a translation to the International Accounting Standards (IAS).

On the contrary side, Lueg et al. (2014) confirms that the transition from UK GAAP to IFRS cause significant increase to profitability(Operating Income Margin, Return on Equity, and Return on Invested Capital) and liquidity ratios(Current Ratio), while the $\mathrm{P} / \mathrm{E}$ ratio decreased as the stock price is held stable (numerator) but net income increases (denominator). Although both UK GAAP and IFRS are market-oriented, the results reveal that there is a difference between both standards that affect a firm's financial performance which is considered one of the scarce evidence of differences between IFRS and common law countries' local GAAP.

On the other hand, studies conducted regarding countries under the civil law regime reveals a difference in accounting practices between IFRS and local GAAP that influence the financial performance of firms. For instance, using a sample of 7 Continental Europe countries, O'Connell and Sullivan (2008) investigate the effect of the compulsory switch to IFRS between Euronext 80 firms on net income. The results show that for approximately $75 \%$ of sample firms, the transition to IFRS results in a statistically significant rise in net income. They find that IFRS 3, Business Combination, is by far the most significant driver of the net income increase observed when firms change from local GAAP to IFRS. using a sample of 91 Finland firms, Lantto and Sahlström (2009) investigated the impact of mandatory IFRS adoption on eight financial ratios and the affected standards from such transition. The findings reveal that after IFRS adoption, the profitability and debt ratios increased, while equity, price-to-earnings and liquidity ratios decrease. These changes may be due to differences between the two standards in the lease, fair value, income tax, and financial instruments accounting standards which affect income statements. This reliable transition could be due to Finland's strong legal system and the authority's strong supervision of the transition process. In addition to Finland's civil law regime which is different from IFRS.

In Greece, Iatridis and Rouvolis (2010) investigated the effect of adopting IFRS on financial performance. The results reveal that the financial measures as profitability, liquidity, and growth decreased in the first year of adoption which may be attributed to the IFRS fair value orientation and the transition expenses connected with it. However, firms showed enhanced financial measures in the following year. A similar finding was also reported by Fitó, Gómez, and Moya (2012) who investigated the consequences of the transition from Spanish GAAP to IFRS-based Spanish Accounting Standards on 12 financial ratios. The results indicate that the application of IFRS has a significant effect on most accounts, especially those in the balance sheet. .In addition, the deferred tax liability shows more liabilities that were not reflected in the balance sheet before IFRS.

In Romania, Neag (2014) investigates the effect of mandatory transition to IFRS on the reported performance. He found no significant effect on both net income and shareholder's equity. However, he found that IFRS has a positive reaction to the stock market. Concerning Chile, Espinosa et al. (2015) analyzed 43 firms to investigate the effect of IFRS on nine financial ratios and the market reaction towards this adoption. They found that IFRS significantly affect profitability and investment ratios and does not affect leverage and price-earnings ratios. They added that the market did not reward this type of initiative. This result could be due to the reality that assets and liabilities under IFRS at fair value which causes volatility in the statement of financial position figures. In addition to the allocation of some unrealized gains and losses to both statements of financial performance and other comprehensive income which may affect profitability and liquidity ratios.

Ntaikou, Vousinas, and Kenourgios (2018) investigated the anticipated effect of adopting IFRS 9 on the Greek banking system's financial performance. He concluded that the absence of published annual reports prepared by banks based on IFRS 9 does not allow the true effect on the financial performance of banks to be captured. Moreover, Using a sample of Italian firms, Magli, Nobolo, and Ogliari (2018) investigated the effect of adopting IFRS 16 on the performance of 
economic entities. The results show that both financial liabilities and lease assets will increase in the statement of financial position, while equity will decrease. Besides, both finance cost and earnings before interest and tax (EBIT) will increase in the statement of financial performance. As a result, both EBIT/revenues ratio and debt/equity ratios will increase.

The studies regarding countries in the Middle East and North Africa (MENA) region reveals a difference in accounting practices between IFRS and local GAAP that influence the financial performance of firms. This was because France has transferred their less shareholders oriented accounting framework to a variety of MENA countries due to previous colonialism. The majority of MENA region countries are affected by both sharia law and civil law which affect the accounting framework. For instance, in Oman, Rawashdeh (2003) investigated the effect of changing from local GAAP to IFRS of 18 firms listed on the Amman Stock Exchange on the stock prices. The results show a significant impact on the stock prices of firms adopting IFRS compared to non-adopting firms. In Algeria, Ramzy (2015) tried to identify whether the adoption of IFRS has an impact on the firms' financial performance. The results show that IFRS significantly affects the financial performance ratios and increases the value relevance of the financial reports. The same result found by Haya (2011). In Egypt, Sawy (2016) compared the quality of financial reports under both Egyptian Accounting Standards and IFRS. The results reveal that earnings management decrease under IFRS which enhances the quality of the financial reports. In the same vein, Ebaid (2016) finds that the adoption of IFRS increased accounting quality in Egypt as a civil-law country. Additionally, Mansour (2017) examined the moderating role of IFRS on the relationship between earnings management and financial firms listed in the Egyptian Stock Exchange. The results show an insignificant moderating relationship to IFRS.Abdalwahab (2018) investigate the effect on the financial performance of one manufacturing firm listed on the Egyptian Stock Exchange of the transition from Egyptian Accounting Standard 20 to IFRS16. They discovered a substantial rise of 17.57 percent of total liabilities in the lease liabilities.

Using a sample of 31 developing countries, Mhedhbi and Zeghal (2016) performed univariate and multivariate analyses to identify the association between the implementation of IFRS and the performance of emerging capital markets. The findings indicate that IFRS is positively associated with the performance of capital markets in developing countries.

It can also be assumed that, in many cases, accounting differences between IFRS and local GAAP could be caused by possible first-time adoption errors, as not all firms were equally prepared for the IFRS implementation process. Khamis (2016) find that the Egyptian accountants and auditors have an insufficient understanding of IFRS15. Interestingly, the studies reviewed do not find any impact on the operating cash flow ratio. The reason may be that cash flows are not influenced by modifications in accounting standards. Using cash flow analysis is suggested, especially in instances where accounting practices are subject to uncertainty or management's sole discretion. Another suggestion is that stakeholders can rely on new ratios that incorporate unrealized gains and losses not disclosed in the statement of financial performance as the comprehensive-ROA and the comprehensive-ROE. The comprehensive income is used in the numerator instead of net income.

Conclusively, the above comparison of the literature shows that IFRS adoption has affected firms' financial performance in lower shareholders oriented countries. This may be attributed to several IFRS standards based on fair value accounting, such as IFRS 2, IAS 39, IAS 16, IFRS 3, and IAS 38 which mostly impacted changes in financial performance ratios following the transition to IFRS in countries under civil law and MENA region countries. However, the magnitude and direction of changes in the financial performance measures rely heavily on the pre-transition differences between local GAAP and IFRS. The more the difference, the more volatile the financial performance measures, particularly the ratios of profitability, and liquidity. Thus we can conveniently answer the third and fourth research questions of whether the financial ratios prepared under IFRS are different from local GAAP and whether they indicate higher performance.

\section{Conclusion}

The objective of this study is to review the literature that investigates the effect of Financial Reporting Standards(FRS) on firms' financial performance to answer a debating question of how effective are the accounting standards in affecting financial performance. This study first investigates the reasons and evidence behind different accounting practices among different countries. The results reveal that the main reason for diversity in the legal system, source of financing and socioeconomic factors. This results in different recognition and measurement rules and hence different accounting practices. Next, the study examines the theories that justify the adoption of IFRS to affect firm performance. The results reveal that the transition from local GAAP is justified by the value maximization theory which claims that the disclosure of IFRS-compliant financial statements by firms will lead to the maximization of the value of the firm and increase profitability ratio.

Next, the study examines the effect of transition from local GAAP to IFRS on financial performance ratios. The results reveal that the majority of studies have shown a significant difference between local GAAPs and IFRS in the financial performance ratios in less shareholders oriented civil law countries. The differences may be attributed to the heavy 
reliance of IFRS on fair value accounting which requires continuous adjustments to accounts and may result for example in unrealized gain and losses that may affect the income statements and other comprehensive income and hence the financial performance ratios. Another justification is that IFRS is a principle-based approach that focuses on setting general principles with limited guidance and encourages the professional judgment of managers to apply the principle to particular transactions. On the other hand, the results show that the majority of studies have shown an insignificant change in financial ratios in more shareholder-oriented common law countries. This was because IFRS resembles local GAAP originated from common law countries. Moreover, no significant differences for countries whose local GAAP was a translation to IAS as Nigeria. Finally, the review investigates whether financial ratios under IFRS indicate higher performance than those under local GAAP. The results of the reviewed studies showed mixed results. The magnitude and direction of the financial performance ratios vary between countries, depending on the pre-transition differences between local GAAP and IFRS. The more the difference, the more volatile the financial performance measures, particularly the ratios of profitability and liquidity.

Several areas may be recognized for future studies. First, identifying the accounting standards that cause volatility in the financial performance ratios after the transition to IFRS in developing countries may be considered an important area for future research. Second, the mediating role of industry and country-level variables as legal system and Corruption Perceptions Index (CPI) that might influence the strength of the relationship between accounting standards adopted and financial performance need to be investigated. Third, the effect of the transition to IFRS is under-researched in developing countries, especially the MENA region. Future studies may concentrate on these countries to inform standard-setters about the cost and benefit of this transition. Finally, the majority of reviewed studied used univariate and multivariate analysis in analyzing clustered data to evaluate expected relationships in cross-level environments without taking into account the methodological limitations of aggregation and disaggregation which may lead to underestimation of standard errors and incorrect estimation and violation to the assumption of least squares regression that cause heteroscedasticity (Salah, 2018). Future studies may employ other methodologies as Hierarchical Linear Modeling (HLM) analysis to examine the effects of IFRS implementation in countries with various institutional, socioeconomic and environmental features.

The findings of this study have several implications. First, it motivates standards setters in countries that do not permit IFRS implementation to impose laws and regulations that encourage the implementation of IFRSs, which will lead to greater convergence of accounting standards worldwide and greater advantages for all participants. Second, it helps managers in assessing other firms' financial statements to assess potential merger and acquisition. In addition, to evaluate a firm's results against competitors. Finally, it enables investors to compare financial statements of firms in different countries which enhance investment decision. This review has a limitation that needs to be mentioned which is only English and Arabic articles are reviewed while other languages were excluded.

\section{References}

Abdalwahab, A. O., Abdullah, A. M., \& Marwan, G. A. (2018). The impact of transition from EAS 20 to IFRS 16 on financial performance.

Abdul-Baki, Z., Uthman, A. B., \& Sannia, M. (2014). Financial ratios as performance measure: A comparison of IFRS and Nigerian GAAP. Accounting and management information systems, 13(1), 82.

Adeuja, Y. O. (2015). A Comparative Approach to the Impact of IFRS (International Financial Reporting Standards) on the Performance of Banks in Nigeria. Eastern Mediterranean University (EMU)-Doğu Akdeniz Üniversitesi (DAÜ).

Alp, A., \& Ustundag, S. (2009). Financial reporting transformation: The experience of Turkey. Critical perspectives on Accounting, 20(5), 680-699. https://doi.org/10.1016/j.cpa.2007.12.005

Armstrong, C. S., Barth, M. E., Jagolinzer, A. D., \& Riedl, E. J. (2010). Market reaction to the adoption of IFRS in Europe. The accounting review, 85(1), 31-61. https://doi.org/10.2308/accr.2010.85.1.31

Atu, O., Atu, O. G., \& Atu, O. V. (2014). A Comparative Study of Accounting Standards in Nigeria, United Kingdom and United States of America. IOSR Journal of Economics and Finance (IOSR-JEF), 1-7.

Bao, D. H., Lee, J., \& Romeo, G. (2010). Comparisons on selected ratios between IFRS and US GAAP companies. Journal of Financial Reporting and Accounting, 8(1), 22-34. https://doi.org/10.1108/19852511011055925

Blanchette, M., Racicot, F. É., \& Girard, J. Y. (2011). The effects of IFRS on financial ratios: Early evidence in Canada.

Boolaky, P. K., Omoteso, K., Ibrahim, M. U., \& Adelopo, I. (2018). The development of accounting practices and the adoption of IFRS in selected MENA countries. Journal of Accounting in Emerging Economies, 8(3), 327-351. https://doi.org/10.1108/JAEE-07-2015-0052

Byard, D., Li, Y., \& Yu, Y. (2011). The effect of mandatory IFRS adoption on financial analysts' information 
environment. Journal of Accounting Research, 49(1), 69-96. https://doi.org/10.1111/j.1475-679X.2010.00390.x

d'Arcy, A. (2001). Accounting classification and the international harmonisation debate-an empirical investigation. Accounting, organizations and society, 26(4-5), 327-349. https://doi.org/10.1016/S0361-3682(00)00036-2

Ding, Y., Hope, O. K., Jeanjean, T., \& Stolowy, H. (2007). Differences between domestic accounting standards and IAS: Measurement, determinants and implications. Journal of accounting and public policy, 26(1), 1-38. https://doi.org/10.1016/j.jaccpubpol.2006.11.001

Doupnik, T., \& Perera, H. (2019). International accounting (fifth ed.): McGraw-Hill Higher Education.

Ebaid, I. E. S. (2016). International accounting standards and accounting quality in code-law countries: The case of Egypt. Journal of Financial Regulation and Compliance, 24(1), 41-59. https://doi.org/10.1108/JFRC-12-2011-0047

Erin, O. A., \& Oduwole, F. (2018). An Investigative Analysis into the Impact of International Financial Reporting Standards (IFRS) on the Profitability Ratios of Nigerian Banks. EuroEconomica, 38(1).

Espinosa, C., Maquieira, C., Diaz, F., \& Abarca, A. (2015). Adoption of IFRS in an emerging market: the Chilean case. Academia Revista Latinoamericana de Administración, 28(4), 442-460. https://doi.org/10.1108/ARLA-11-2014-0191

Fitó, A., Gómez, F., \& Moya, S. (2012). Choices in IFRS adoption in Spain: determinants and consequences. Accounting in Europe, 9(1), 61-83. https://doi.org/10.1080/17449480.2012.664390

Horton, J., Serafeim, G., \& Serafeim, I. (2013). Does mandatory IFRS adoption improve the information environment? Contemporary accounting research, 30(1), 388-423. https://doi.org/10.1111/j.1911-3846.2012.01159.x

Houqe, N. (2018). A review of the current debate on the determinants and consequences of mandatory IFRS adoption. International Journal of Accounting \& Information Management, 26(3), 413-442. https://doi.org/10.1108/IJAIM-03-2017-0034

Iatridis, G., \& Rouvolis, S. (2010). The post-adoption effects of the implementation of International Financial Reporting Standards in Greece. Journal of International Accounting, Auditing and Taxation, 19(1), 55-65. https://doi.org/10.1016/j.intaccaudtax.2009.12.004

Jermakowicz, E. K., Chen, C. D., \& Donker, H. (2018). Financial statement effects of adopting IFRS: the Canadian experience. International Journal of Accounting \& Information Management, 26(4), 466-491. https://doi.org/10.1108/IJAIM-08-2017-0096

Jermakowicz, E. K., \& Gornik-Tomaszewski, S. (2006). Implementing IFRS from the perspective of EU publicly traded companies. Journal of International Accounting, Auditing and Taxation, 15(2), 170-196. https://doi.org/10.1016/j.intaccaudtax.2006.08.003

Katz, M. L., \& Shapiro, C. (1985). Network externalities, competition, and compatibility. American economic review, 75(3), 424-440.

Khamis, A. M. (2016). Perception of Preparers and Auditors on New Revenue Recognition Standard (IFRS 15): Evidence From Egypt. Jurnal Dinamika Akuntansi dan Bisnis, 3(2), 1-18. https://doi.org/10.24815/jdab.v3i2.5383

Kitchenham, B. (2004). Procedures for performing systematic reviews. Keele, UK, Keele University, 33(2004), 1-26.

Lantto, A. M., \& Sahlström, P. (2009). Impact of International Financial Reporting Standard adoption on key financial ratios. Accounting \& Finance, 49(2), 341-361. https://doi.org/10.1111/j.1467-629X.2008.00283.x

Larson, R. K., \& Kenny, S. Y. (2011). The financing of the IASB: An analysis of donor diversity. Journal of International Accounting, Auditing and Taxation, 20(1), 1-19. https://doi.org/10.1016/j.intaccaudtax.2010.12.003

Lueg, R., Punda, P., \& Burkert, M. (2014). Does transition to IFRS substantially affect key financial ratios in shareholder-oriented common law regimes? Evidence from the UK. Advances in accounting, 30(1), 241-250. https://doi.org/10.1016/j.adiac.2014.03.002

Magli, F., Nobolo, A., \& Ogliari, M. (2018). The Effects on Financial Leverage and Performance: The IFRS 16. International Business Research, 11(8), 76-89. https://doi.org/10.5539/ibr.v11n8p76

Mhedhbi, K., \& Zeghal, D. (2016). Adoption of international accounting standards and performance of emerging capital markets. Review of Accounting and Finance, 15(2), 252-272. https://doi.org/10.1108/RAF-08-2013-0099

Naderian, A., \& Mahadevappa, B. (2014). A Study of Differences in Financial Performance under Indian GAAP and IFRS: Case of Noida Toll Bridge Company Limited. SDMIMD Journal of Management, 5(1), 15-23. https://doi.org/10.15533/sdm/2014/v5i1/47417 
Neag, R. (2014). The effects of IFRS on net income and equity: evidence from Romanian listed companies. Procedia economics and finance, 15, 1787-1790. https://doi.org/10.1016/S2212-5671(14)00860-0

Newman, W., Edmore, T., Milondzo, K., \& Vongai, O. W. (2016). A literature review on the impact of IAS/IFRS and regulations on quality of financial reporting. Risk Governance and Control: Financial Markets \& Institutions, 6(4). https://doi.org/10.22495/rcgv6i4art13

Ntaikou, D., Vousinas, G., \& Kenourgios, D. (2018). The expected impact of IFRS 9 on the Greek banking system's financial performance: some theoretical considerations and insights. Paper presented at the 9th National Conference of the Financial Engineering and Banking Society, Athens, Greece.

O'Connell, V., \& Sullivan, K. (2008). The impact of mandatory conversion to IFRS on the net income of FTSEurofirst 80 firms. Journal of Applied Research in Accounting and Finance (JARAF), 3(2), 17.

Ott, D. L., \& Michailova, S. (2018). Cultural Intelligence: A Review and New Research Avenues. International Journal of Management Reviews, 20(1), 99-119. https://doi.org/10.1111/ijmr.12118

Parrott, K. M. (2017). A Quantitative Study on the Difference between US GAAP and IFRS Measuring Comparability with Financial Ratios. Northcentral University,

Programme, C. A. S. (2013). 10 questions to help you make sense of qualitative research. In: Public Health Resource Unit: England.

Rawashdeh, M. (2003). Effects of introducing international accounting standards on Amman stock exchange. Journal of American Academy of Business, Cambridge, 3(1-2), 361-361.

Samaha, K., \& Khlif, H. (2016). Adoption of and compliance with IFRS in developing countries: a synthesis of theories and directions for future research. Journal of Accounting in Emerging Economies, 6(1), 33-49. https://doi.org/10.1108/JAEE-02-2013-0011

Spence, M. (1978). Job market signaling. In Uncertainty in economics (pp. 281-306): Elsevier. https://doi.org/10.1016/B978-0-12-214850-7.50025-5

Tanko, M. (2012). The effect of international financial reporting standards (IFRS) adoption on the performance of firms in Nigeria. Journal of Administrative and Economic Sciences, 5(2), 133-157.

Uzoma, A. B., FO, O., AA, B., FOLASHADE, O., DORCAS, A. J. T. J. o. I. B., \& Commerce. (2016). Adoption of international financial reporting standards and its implication on bank performance in Nigeria: A comparative approach. 2l(3).

von Alberti-Alhtaybat, L., Hutaibat, K., \& Al-Htaybat, K. (2012). Mapping corporate disclosure theories. Journal of Financial Reporting and Accounting, 10(1), 73-94. https://doi.org/10.1108/19852511211237453

Weigel, T. (2011). A New Universal Language: An Overview of Adopting the International Financial Reporting Standards in the United States. UMKC L. Rev., 80, 1239.

Zeller, T. (2019). An IFRS-based taxonomy of financial ratios. Accounting Research Journal, 32(1), 20-35. https://doi.org/10.1108/ARJ-10-2017-0167

$$
\begin{aligned}
& \text { الصاوى, ن. ه. م. 2016. أثر تطبيق المعايير الدولية لإعداد التقارير المالية "IFRS" على درجة الإعتماد على مؤشرات مخاطر الغش. ماجستير, جامعة } \\
& \text { القاهرة ـ كلية التجارة ـ المحاسبة. } \\
& \text { حياة, ب. 2011. دور المعلومات المحاسبية في تحسين الأداء المالي للمؤسسة الاقتصادية, دراسة حالة مؤسسة المطاحن الكبرى للجنوب :.جامعة محلم } \\
& \text { خيضر. } \\
& \text { رمزي, ج. م. 2015. أثر تطبيق معايير الثقارير المالية الدولية على تقيبم الأداء المالي في المؤسسات الجزائرية ـالمعيار المحاسبي الدولي 1عرض القوائم } \\
& \text { المالية. دكتور اة, جامعة محمد خيضر - بسكرة. } \\
& \text { لطفي,أ. أ.2007 ـ التحليل المالى لأغر اض تقييم و مر اجعة الأداء و الاستثمار فى البورصة. الدار الجامعية. الإسكندرية. }
\end{aligned}
$$

\section{Copyrights}

Copyright for this article is retained by the author(s), with first publication rights granted to the journal.

This is an open-access article distributed under the terms and conditions of the Creative Commons Attribution license which permits unrestricted use, distribution, and reproduction in any medium, provided the original work is properly cited. 